\title{
PERBEDAAN KEBERADAAN JENTIK $A E D E S$ AEGYPTI ANTARA BAK MANDI DI PERDESAAN DAN PERKOTAAN DI KECAMATAN WONOGIRI
}

\author{
THE DIFFERENCE OF EXISTENCE OF AEDES AEGYPTI LARVA BETWEEN \\ BATH-TUB IN RURAL AREA AND BATHTUB IN URBAN AREA IN WONOGIRI SUB- \\ DISTRICT
}

\author{
Muhammad Nur Sidiq, Iskandar, Yusuf Alam Romadhon \\ Fakultas Kedokteran, Universitas Muhammadiyah Surakarta \\ Korespondensi: dr. Yusuf Alam Romadhon, MKes, Email: yusuf_alam@ums.ac.id
}

\begin{abstract}
ABSTRAK
Pemeriksaan jentik Aedes aegypti dilakukan dalam mengurangi angka kesakitan demam berdarah dengue. Tujuan dari penelitian ini adalah mengetahui perbedaan jumlah jentik Aedes aegypti antara bak mandi di perdesaan dan perkotaan .Penelitian ini menggunakan jenis penelitian observasional analitik dengan pendekatan cross sectional. Penelitian dilakukan di wilayah Kecamatan Wonogiri pada bulan Oktober-November 2015. Besar sampel adalah 100 responden di wilayah Kecamtan Wonogiri yang tersebar di 15 kelurahan dan desa. Uji statistik yang digunakan adalah Chi square. Hasil penelitian menunjukkan bahwa jumlah jentik Aedes aegypti di perkotaan lebih banyak daripada di perdesaan (42\% vs 14\%) dengan $p=<0,002$. Kesimpulan: jumlah jentik Aedes aegypti di perkotaan lebih banyak daripada di perdesaan di kecamatan Wonogiri.
\end{abstract}

Kata kunci. Keberadaan jentik, Aedes aegypti, Bak mandi, Perdesaan, Perkotaan

\section{ABSTRACT}

A checking of Aedes aegypti was done to reducing the number of dengue sickness. The aim of this research is to know the difference of the number of larvae of Aedes aegypti in bathtub rural and urban areas. This research was observational analitical research using a cross sectional approach. This research was conducted in the area of Wonogiri Sub-district in October-November 2015. The amount of sample was 100 respondents in Wonogiri Subdistrict area distributed in 15 urban and rural villages. The statistical test used was Chi square.The existence of Aedes aegypti larva in urban area was more than the one in rural area (42\% vs $14 \%)$ with $p$. 0.002.Conclusion: The existence of Aedes aegypti larva in urban area was more than the one in rural area in Wonogiri Subdistrict.

Keyword. The existence of larva, Aedes aegypti, Bath-tub, Rural area, Urban area

\section{PENDAHULUAN}

Penyakit Demam Berdarah Dengue (DBD) adalah penyakit menular yang disebabkan oleh virus dengue yang ditularkan oleh nyamuk Aedes aegypti dan Aedes albopictus. Menurut prevalensi di dunia didapatkan bahwa ada 50 juta kasus DBD tiap tahunnya di daerah endemik. Data di dunia menunjukkan bahwa Asia menempati urutan pertama dengan kasus DBD terbanyak di dunia pada tiap tahunnya, contohnya di Indonesia, Sri Lanka, Timor Leste, Myanmar, dan Thailand dengan kondisi nyamuk Aedes aegypti tersebar di perkotaan dan perdesaan (WHO, 2011).
Sejak tahun 1968 sampai 2009, World Health Organization (WHO) mencatat bahwa negara Indonesia sebagai negara dengan kasus DBD tertinggi di Asia Tenggara (Depkes, 2012). Dari data internasional yang ada tersebut diharapkan bisa mendukung untuk pengawasan epidemiologi dalam lingkup nasional (Lin et al, 2013).

Dari data yang didapat, angka kejadian DBD di Indonesia semakin lama semakin meningkat. Awal mula munculnya insidensi DBD di Indonesia yaitu di kota Jakarta dan di Surabaya pada tahun 
1968. Dengan peningkatan jumlah penderita terjadi setiap 5 tahun. Pada tahun 1988, terjadi Kejadian Luar Biasa (KLB) yang terakhir dengan jumlah penderita 47.573 dan dengan jumlah yang meninggal 1.527 Case Fatality Rate (CFR 3,2\%). Angka Bebas Jentik (ABJ) secara nasional pada tahun 2008 adalah $85,7 \%$, mengalami penurunan pada tahun 2009 (ABJ 71,1\%) dan meningkat pada tahun 2010, yaitu ABJ sebesar 81,4\%. Ditambah lagi pada tahun 2008 provinsi Jawa Tengah menduduki peringkat 10 angka Angka Kesakitan/ Incident Rate (IR) DBD terbanyak di Indonesia. Ketika melihat ke bawah lagi yaitu di provinsi Jawa Tengah, penyakit DBD masih merupakan masalah yang serius dengan bukti bahwa dari 35 kabupaten yang ada, kesemuanya telah terjangkit DBD. Angka Kesakitan/ Incident Rate (IR) tahun 2012 adalah 19,29/100.000 penduduk, meningkat bila dibandingkan tahun 2011 yaitu $(15,27 /$ 100.000) penduduk. Padahal ketika mengacu dengan target nasional, Angka Kesakitan/ Incident Rate (IR) adalah sebesar $<20 / 100.000$ penduduk. Sehingga dengan Angka Kesakitan/ Incident Rate (IR) yang hampir mendekati target nasional, maka diharapkan segera dilakukan perawatan penderita, inspeksi lapangan dan pendataan epidemiologi (Depkes, 2010).

Salah satu kabupaten di Jawa Tengah yang memiliki angka kesakitan DBD adalah kabupaten Wonogiri, wilayah yang terletak di bagian tenggara provinsi Jawa Tengah. Pada tahun 2012 kabupaten Wonogiri memiliki Angka Kematian/ Case Fatality rate (CFR) sebesar 1,52\%, sehingga bisa dikatakan lebih tinggi dibanding target nasional yaitu (<1\%) (Depkes, 2012). Kabupaten Wonogiri memiliki jumlah kecamatan sebanyak 25 kecamatan. Dari 25 kecamatan tersebut, kecamatan Wonogiri merupakan salah satu di antaranya. Menurut perda (peraturan daerah) nomer 9 tahun 2011 dijelaskan mengenai pembagian wilayah perdesaan dan perkotaan di kecamatan Wonogiri. Sesuai dengan pasal 34 ayat 2 wilayah perkotaan meliputi: kelurahan Sendang, Wuryorejo, Pokoh Kidul, Bulusulur, Wonoboyo, Giripurwo, Giritirto, Giriwono, dan Wonokarto. Sedangkan wilayah perdesaan meliputi; kelurahan Manjung, Purworejo, Purwosari, Sonoharjo,
Wonoharjo, dan Wonokerto. Sehingga kecamatan wonogiri memiliki total 15 kelurahan..

Berdasarkan data yang terpapar di atas maka dilakukanan penelitian untuk mengetahui perbedaan keberadaan jentik Aedes aegypti antara bak mandi di perdesaan dan perkotaan.

\section{METODE}

Pada penelitian ini, peneliti menggunakan jenis penelitian observasional analitik dengan pendekatan cross sectional. Penelitian dilakukan di kecamatan Wonogiri, kabupaten Wonogiri, provinsi Jawa Tengah dengan waktu penelitian pada bulan September 2015. Variabel bebas pada penelitian ini adalah bak mandi di perdesaan dan perkotaan serta variabel terikatnya adalah keberadaan jentik Aedes aegypti.

Sampel dalam penelitian ini adalah 100 rumah yang telah terhitung sebagai sampel penelitian dengan menggunakan teknik cluster random sampling, yaitu skema pengambilan sampel dimana unit sampel adalah kelompok atau klaster, bukannya individu. Analisis data dalam penelitian ini menggunakan analisis statistic $C h i$ square serta menggunakan software SPSS 19.0 for windows.

\section{HASIL DAN PEMBAHASAN}

Responden dalam penelitian ini adalah rumah yang berada di kecamatan Wonogiri. Kecamatan Wonogiri mempunyai luas wilayah $82,92 \mathrm{~km}^{2}$ dan mempunyai jumlah penduduk sekitar 93,369 jiwa per September 2015. Kecamatan Wonogiri terdiri dari 9 desa dan 6 kelurahan. Dimana dari 9 desa adalah masuk wilayah perdesaan dan 6 kelurahan masuk dalam wilayah perkotaan. Dari 9 desa tersebut yaitu, desa Bulusulur, desa Manjung, desa Pokoh Kidul, desa Porworejo, desa Porwosari, desa Sendang, desa Sonoharjo, desa Wonoharjo, dan desa Wonokerto. Sedangkan untuk 6 kelurahan di kecamatan Wonogiri yaitu kelurahan Giripurwo, kelurahan Giritirto, kelurahan Giriwono, kelurahan Wonoboyo, kelurahan Wonokarto, dan kelurahan Wuryorejo. 
Tabel 1. Distribusi RespondenBerdasarkan Pembagian Wilayah

\begin{tabular}{|c|c|c|}
\hline Wilayah & $\mathrm{N}$ & $\%$ \\
\hline Perdesaan & 7 & 14 \\
\hline Perkotaan & 21 & 42 \\
\hline Total & 28 & 56 \\
\hline
\end{tabular}

Tabel 2. Distribusi Responden Berdasarkan Umur Kepala Keluarga di Perdesaan dan Perkotaan

\begin{tabular}{ccccc}
\hline \multirow{2}{*}{ Umur } & \multicolumn{2}{c}{ Perdesaan } & \multicolumn{2}{c}{ Perkotaan } \\
\cline { 2 - 5 } & $\mathrm{N}$ & $\%$ & $\mathrm{~N}$ & $\%$ \\
\hline $\mathbf{3 0 - 4 0}$ & 4 & 8 & 14 & 28 \\
$\mathbf{4 1 - 5 0}$ & 21 & 42 & 20 & 40 \\
$\mathbf{5 1 - 6 0}$ & 19 & 38 & 10 & 20 \\
$\mathbf{6 1 - 7 0}$ & 6 & 12 & 6 & 12 \\
\hline Total & 50 & 100 & 50 & 100 \\
\hline
\end{tabular}

Tabel 3. Distribusi Responden Berdasarkan Jenis Kelamin Kepala Keluarga di Perdesaan dan Perkotaan

\begin{tabular}{ccccc}
\hline \multirow{2}{*}{ Jenis Kelamin } & \multicolumn{3}{c}{ Perdesaan } & \multicolumn{2}{c}{ Perkotaan } \\
\cline { 2 - 5 } & $\mathbf{N}$ & $\mathbf{\%}$ & $\mathbf{N}$ & $\mathbf{\%}$ \\
\hline Laki-laki & 50 & 100 & 50 & 100 \\
Perempuan & 0 & 0 & 0 & 0 \\
\hline Total & 50 & 100 & 50 & 100 \\
\hline
\end{tabular}

Tabel 4. Distribusi Responden Berdasarkan PendidikanFormal di Perdesaan dan Perkotaan

\begin{tabular}{lcccc}
\hline \multicolumn{1}{c}{ Pendidikan } & \multicolumn{2}{c}{ Perdesaan } & \multicolumn{2}{c}{ Perkotaan } \\
\cline { 2 - 5 } \multicolumn{1}{c}{ Formal } & $\mathrm{N}$ & $\%$ & $\mathrm{~N}$ & $\%$ \\
\hline SD & 9 & 18 & 1 & 2 \\
SMP & 6 & 12 & 4 & 8 \\
SMA/SMK & 14 & 28 & 3 & 6 \\
D3 & 11 & 22 & 7 & 14 \\
SI & 10 & 20 & 27 & 54 \\
S2 & 0 & 0 & 8 & 16 \\
\hline Total & 50 & 100 & 50 & 100 \\
\hline
\end{tabular}

Tabel 5. Distribusi Responden Berdasarkan Pekerjaan di Perdesaan dan Perkotaan

\begin{tabular}{lcccc}
\hline \multirow{2}{*}{ Pekerjaan } & \multicolumn{2}{c}{ Perdesaan } & \multicolumn{2}{c}{ Perkotaan } \\
\cline { 2 - 5 } & $\mathrm{N}$ & $\%$ & $\mathrm{~N}$ & $\%$ \\
\hline Petani & 21 & 42 & 0 & 0 \\
PNS & 11 & 22 & 30 & 60 \\
Wiraswasta & 13 & 26 & 17 & 34 \\
Pensiun & 5 & 10 & 3 & 6 \\
\hline Total & 50 & 100 & 50 & 100 \\
\hline
\end{tabular}


Tabel 6. Distribusi Responden Berdasarkan Pendapatan Per Bulan di Perdesaan dan Perkotaan

\begin{tabular}{lcccc}
\hline Pendapatann Per & \multicolumn{2}{c}{ Perdesaan } & \multicolumn{2}{c}{ Perkotaan } \\
\cline { 2 - 5 } \multicolumn{1}{c}{ Bulan } & $\mathrm{N}$ & $\%$ & $\mathrm{~N}$ & $\%$ \\
\hline$\geq 1$ juta & 26 & 52 & 0 & 0 \\
$\geq 2$ juta & 13 & 26 & 3 & 6 \\
$\geq 3$ juta & 10 & 20 & 14 & 28 \\
$\geq 4$ juta & 1 & 2 & 33 & 66 \\
\hline Total & 50 & 100 & 50 & 100 \\
\hline
\end{tabular}

Tabel 7. Distribusi Responden Berdasarkan Pendapatan Per Bulan di Perdesaan dan Perkotaan

\begin{tabular}{lcccc}
\hline \multicolumn{1}{c}{ Pendapatan Per } & \multicolumn{2}{c}{ Perdesaan } & \multicolumn{2}{c}{ Perkotaan } \\
\cline { 2 - 5 } \multicolumn{1}{c}{ Bulan } & $\mathrm{N}$ & $\%$ & $\mathrm{~N}$ & $\%$ \\
\hline$\geq 1$ juta & 26 & 52 & 0 & 0 \\
$\geq 2$ juta & 13 & 26 & 3 & 6 \\
$\geq 3$ juta & 10 & 20 & 14 & 28 \\
$\geq 4$ juta & 1 & 2 & 33 & 66 \\
\hline Total & 50 & 100 & 50 & 100 \\
\hline
\end{tabular}

Tabel 8. Analisis perbedaan antara keberadaan jentik Aedes aegypti antara bak mandi Odi perdesaan dan di perkotaan

\begin{tabular}{llllllll}
\hline \multirow{2}{*}{$\begin{array}{c}\text { Keberadaan } \\
\text { jentik }\end{array}$} & \multicolumn{5}{c}{ Letak Bak mandi } & \multirow{2}{*}{ X } & \multirow{2}{*}{ PR (CI 95\%) } \\
\cline { 2 - 5 } & Perdesaan & $\%$ & Perkotaan & $\%$ & & & \\
\hline Ada & 7 & $7 \%$ & 21 & $21 \%$ & & & \\
\hline Tidak ada & 43 & $43 \%$ & 29 & $29 \%$ & 9,722 & $<0,002$ & 3,000 \\
\hline Total & 50 & $50 \%$ & 50 & $50 \%$ & & & $(1,403-6,417)$ \\
\hline
\end{tabular}

Berdasarkan pengamatan bak mandi di perdesaan dan di perkotaan dengan melihat keberadaan jentik Aedes aegypti, didapatkan hasil bahwa bak mandi di perkotaan lebih banyak terdapatjentik Aedes aegypti daripada di perdesaan. Hal ini membuktikan bahwa tempat penampungan air (TPA) terutama bak mandi adalah merupakan salah satu tempat perkembangbiakan yang disukai nyamuk Aedes aegypti (Trapsilowati dkk, 2010).

Tempat penampungan air (TPA) adalah sarana atau wadah penyimpanan air yang hampir dimiliki oleh seluruh rumah. Hal ini karena dengan menggunakan TPA maka penggunaan air akan lebih terkontrol. Selain itu dengan menggunakan TPA maka dapat menjadi cadangan air jika sewaktuwaktu aliran atau pasokan air terhenti. Namun disamping banyaknya manfaat penggunaan TPA khususnya bak mandi, masih banyak masyarakat yang mengesampingkan kondisi bak mandi terutama dari segi kebersihan. Banyak bak mandi ketika dalam kondisi terisi air, namun masyarakat hanya membiarkanya saja tanpa ada langkah- langkah pengurasan atau penutupan, sehingga bak mandi akan menjadi tempat perindukan nyamuk dan lama kelamaan akan ada jentik-jentik Aedes aegypti di dalamnya (Kusumawardani dkk, 2012).

Dari menganalisis hasil penelitian yang telah dilakukan maka didapatkan hasil bahwa terdapat perbedaan tentang keberadaan jentik Aedes aegypti antara bak mandi di perdesaan dan perkotaan. Sehingga bisa dikatakan bahwa letak bak mandi akan mempengaruhi dari keberadaan jentik Aedes aegypti, di mana bak mandi di perkotaan akan lebih banyak terdapat jentik daripada dengan bak mandi di pedesaan. Kemudian dari pemaparan beberapa tabel di atas seperti jenis kelamin kepala keluarga, pendidikan, pekerjaan, dan penghasilan yang diperoleh oleh kepala keluarga di perkotaan, dapat diambil kesimpulan bahwa walaupun seorang kepala keluarga memiliki jenjang pendidikan yang tinggi dan pendapatan yang tinggi, belum tentu memiliki kondisi bak mandi yang bebas dari jentik Aedes aegypti. Sebaliknya dengan di perdesaan, walaupun kebanyakan kepala keluarga 
di perdesaan memiliki jenjang pendidikan dan pendapatan di bawah kepala keluarga di perkotaan, namun memiliki kondisi bak mandi yang lebih bebas dari jentik Aedes aegypti. Namun dari tabel di atas juga dapat diambil beberapa kesimpulan sehingga bak mandi di perdesaan lebih bebas dari jentik Aedes aegypti daripada di perkotaan. Pertama, bahwa waktu luang masyarakat di perdesaan lebih banyak sehingga bisa meluangkan waktu untuk mempbersihkan bak mandi, hal ini bisa di lihat dari pekerjaan masyarakat yang mayoritas adalah petani. Kedua, karena dalam melakukan penelitian ini saat musim kemarau sehingga ketersediaan air di perdesaan sangat minim, sehingga kondisi bak mandi tidak akan terlalu kotor.

Secara umum pola sebaran nyamuk Aedes aegypti lebih dominan di daerah domestik yang mana mempunyai hubungan yang erat atau berkorelasi positif dengan wilayah urban atau perkotaan. Selain itu ada beberapa faktor dasar sehingga dapat mempengaruhi keberadaan nyamuk Aedes aegypti, seperti perilaku istirahat nyamuk Aedes aegypti dan vegetasi yang berada di lingkungan perkotaan. Salah satu contoh adalah bahwasanya nyamuk Aedes aegypti lebih suka lingkungan dengan tanaman hias yang mana hal tersebut banyak sekali ditemukan di perkotaan. Hal ini sesuai dengan penelitian yang telah dilakukan sebelumnya, yang mengatakan bahwa kondisi lingkungan dan vegetasi seperti di perkotaan akan lebih disukai oleh nyamuk Aedes aegypti. Sehingga secara langsung akan mempengaruhi dari keberadaan jentik Aedes aegypti (Pramestuti dkk, 2013).

Mengenai keberadaan jentik Aedes aegypti di wilayah perkotaan, juga erat kaitanya dengan kebiasaan menyimpan air disamping pengatahuan masyarakat dan pola persebaran nyamuk Aedes aegypti itu sendiri. Karena dari penelitian yang telah dilakukan, ditemukan banyak sekali bak mandi di perkotaan yang melimpah akan air, sehingga dengan kondisi air yang melimpah akan menjadi tempat yang potensial untuk perkembangbiakan nyamuk Aedes aegypti. Disamping itu, dengan kondisi kamar mandi yang lembab dan tertutup, akan cenderung menjadi tempat istirahat yang disukai oleh nyamuk Aedes aegypti. Selain itu juga dari penelitian yang telah dilakukan oleh Anton sebelumnya, dikatakan juga bahwa indeks Aedes aegypti di negara Singapura paling tinggi di wilayah perumahan, rumah toko, dan flat bertingkat (Sitio, 2008).

Pada penelitian yang telah dilakukan, tidak sepenuhnya peneliti lancar dalam melakukan penelitian. Banyak hal-hal yang menjadi penghambat peneliti dalam melakukan penelitian, seperti warga yang sulit ditemui dan enggan untuk diperiksa bak mandi di rumahnya. Kemudian dalam penelitian yang telah dilakukan, peneliti menggunakan metode cross sectional. Metode tersebut bisa dikatakan adalah metode yang cepat dan mudah, namun pada dasarnya dengan metode cross sectional maka akan didapatkan hasil yang tidak dapat dibedakan antara sebab dan akibat. Sehingga diperlukan penelitian lebih lanjut guna mengetahui faktor resiko dan efek yang akan mempengaruhi ada dan tidaknya jentik Aedes aegypti di perdesaan dan perkotaan.

\section{SIMPULAN}

Berdasarkan hasil analisis yang telah dilakukan, maka didapatkan kesimpulan bahwa terdapat perbedaan keberadaan jentik Aedes aegypti antara bak mandi di perdesaan dan di perkotaan di Kecamatan Wonogiri.

\section{DAFTAR PUSTAKA}

Depkes RI. 2010. Demam Berdarah Dengue. Jakarta: Depkes RI.

Dinkes Jateng. 2012. Buku Profil Kesehatan Propinsi Jawa Tengah. Semarang: Dinkes Jateng.

Kusumawardani E dan Achmadi U.F., 2012 Demam Berdarah Dengue di Perdesaan. Jurnal Kesehatan Masyarakat Nasional. Vol. 7. No. 3:120-125

Lin C.Y., Huang C.H., Chen Y.H., 2013. Classification of Dengue: The Clinical Use of World Health Organization 2009 Guideline.Journal of the Formosan Medical Association. Vol. 112. No.2: 61-63.

Pramestuti N dan Djati A.P., 2013. Distribusi Vektor Demam Berdarah Dengue (DBD) Daerah Perkotaan Dan Perdesaan di Kabupaten Banjarnegara. Jurnal Penelitian Kesehatan. Vol. 41. No 3:163-170. 
Sitio A., 2008. Hubungan Perilaku Tentang Pemberantasan Sarang Nyamuk dan Kebiasaan Keluarga dengan Kejadian Demam Berdarah Dengue di Kecamatan Medan Perjuangan Kota Medan. Program Pasca Sarjana Undip. Tesis.

Trapsilowati W., Susanti L., Pujianti A., 2010. Gambaran Kemudahan Memperoleh Air Dan Sarana Penyimpanan Air Terhadap Kasus DBD Di Kota Semarang, Kabupaten Wonosobo, Dan Kabupaten Jepara. Jurnal Vektora. Vol. 2. No 1:1-13.
World Health Organization. 2011. Comprehensive Guidelines for Prevention and Control of Dengue and Dengue Haemorrhagic Fever. Technical Publication Series No. 60: 1-196. 